\title{
Diagnosis of Forcipomyia sahariensis Kieffer (Diptera: Ceratopogonidae) with the first description of immature stages
}

\author{
Aleksandra LEWAŃCZYK, Ryszard SZADZIEWSKI and Patrycja DOMINIAK \\ Department of Invertebrate Zoology, University of Gdańsk, Marszałka Pitsudskiego 46, 81-378 Gdynia, Poland; \\ e-mail: biorys@univ.gda.pl
}

\begin{abstract}
Forcipomyia sahariensis Kieffer, 1923 is diagnosed in all stages. Larvae and pupae reared from rotting roots are described for the first time. Forcipomyia tuzeti Huttel et Huttel, 1952 from France and $F$. acanthophora Remm in Havelka, 1976 from Germany are recognized as new junior synonyms of $F$. sahariensis. A supplemented key for identification of known larvae and pupae of Polish species of the subgenus Forcipomyia s. str. is also provided.
\end{abstract}

Key words: Diptera, Ceratopogonidae, Forcipomyia, diagnosis, larva, pupa, new synonymy, Poland.

\section{INTRODUCTION}

Biting midges of the genus Forcipomyia Meigen are distributed worldwide and common in almost all terrestrial habitats. Over one thousand recent species are known in the genus, which are classified into about 30 more or less distinct subgenera (Borkent \& Wirth 1997, Borkent 2009). There are known 36 species of the genus Forcipomyia in Poland including 16 in the subgenus Forcipomyia s. str. (Szadziewski 2007, Dominiak \& Michalczuk 2009). Giłka (1996) described immature stages of some species in the subgenus Forcipomyia and provided keys for identification of larvae and pupae of nine Polish species. Subsequently Forcipomyia radicicola EDWARDS with immatures described by Saunders (1924) and F. squamigera (Kieffer) were reported from Poland (Szadziewski \& Borkent 2003, Szadziewski et al. 2007).

In this paper we describe larvae and pupae of Forcipomyia sahariensis for the first time and we present modified diagnoses for adults and propose new synonyms. Additionally, we illustrate for the first time special organs in the neck region of the larval prothorax of $F$. radicicola. Larvae and pupae of $F$. sahariensis, $F$. radicicola and $F$. squamigera are incorporated into the keys for identification of Polish species of the subgenus.

\section{MATERIAL AND METHODS}

Larvae and pupae of Forcipomyia sahariensis were collected in NE Poland: Wyskok near Keptrzyn on 5th April 2009. They were observed within large colonies of F. radicicola living in rotting roots of an undetermined umbelliferous plant (Apiaceae) and Arctium lappa. In the laboratory we selected 4 larvae and 10 pupae for descriptions, and reared 4 females and 24 males which emerged from 20 April to 1 May 2009. Larvae, pupae and adults were dissected and mounted on slides in a mixture of phenol-Canada balsam as described by Wirth \& Marston (1968). They are preserved in the collection of the Department of Invertebrate Zoology, University of Gdanisk. SEM microphotographs of $F$. radicicola were made by Dr Magdalena Kowalewska-Groszkowska of the Museum and Institute of Zoology, Polish Academy of Sciences, Warsaw. 


\section{RESULTS}

\section{Forcipomyia sahariensis Kieffer, 1923}

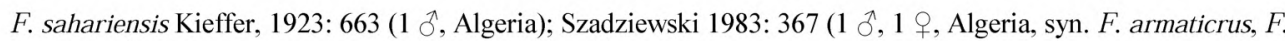
onusta).

F. armaticrus Kieffer, 1923: 661 (1 ㅇ, Algeria).

F. tuzeti Huttel et Huttel, 1952: 178 ( 1 đo, France), n. syn.

F. acanthophora Remm in Havelka, 1976: 227 (1 O, Germany), n. syn.

F. onusta Remm, 1980: 122 (1 §̃, 1 ㅇ, Caucasus, Middle Asia, Sakhalin).

Diagnosis: Immature stages and adults of Forcipomyia sahariensis can be easily distinguished among other species of the subgenus Forcipomyia s. str. by the following combination of characters:

Larva: Body seta $b$ and $d$ densely serrated; seta a lanceolate; cuticle covered with short spines; head setae $p$ and $q$ lanceolate (Figs. 1, 2).

Pupa: Head with 1 pair of processes $b$ bearing short seta; thoracic processes $f$ absent; abdominal segments 1-4 with 3 pairs of very short dorsal and 1 pair of lateral processes (Fig. 3 ).

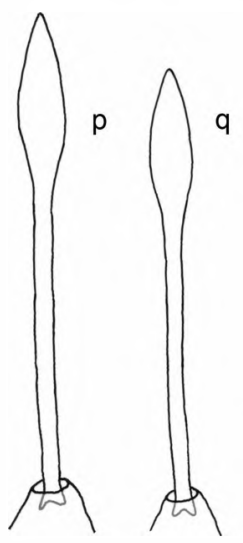

\section{1}

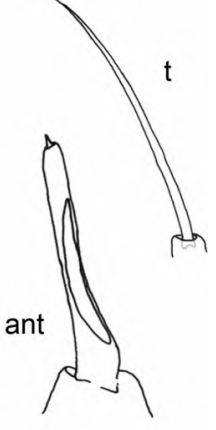

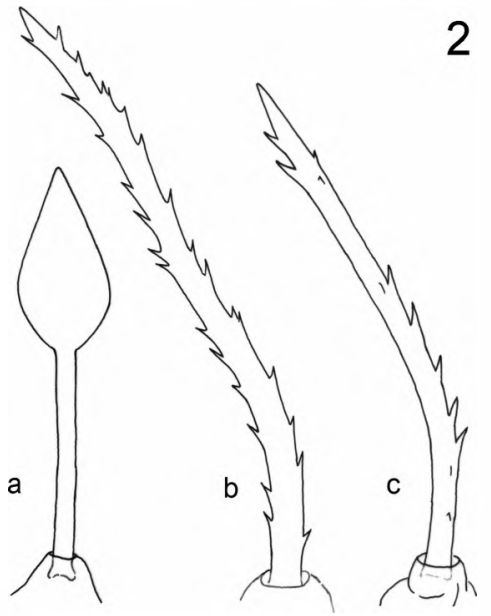

2
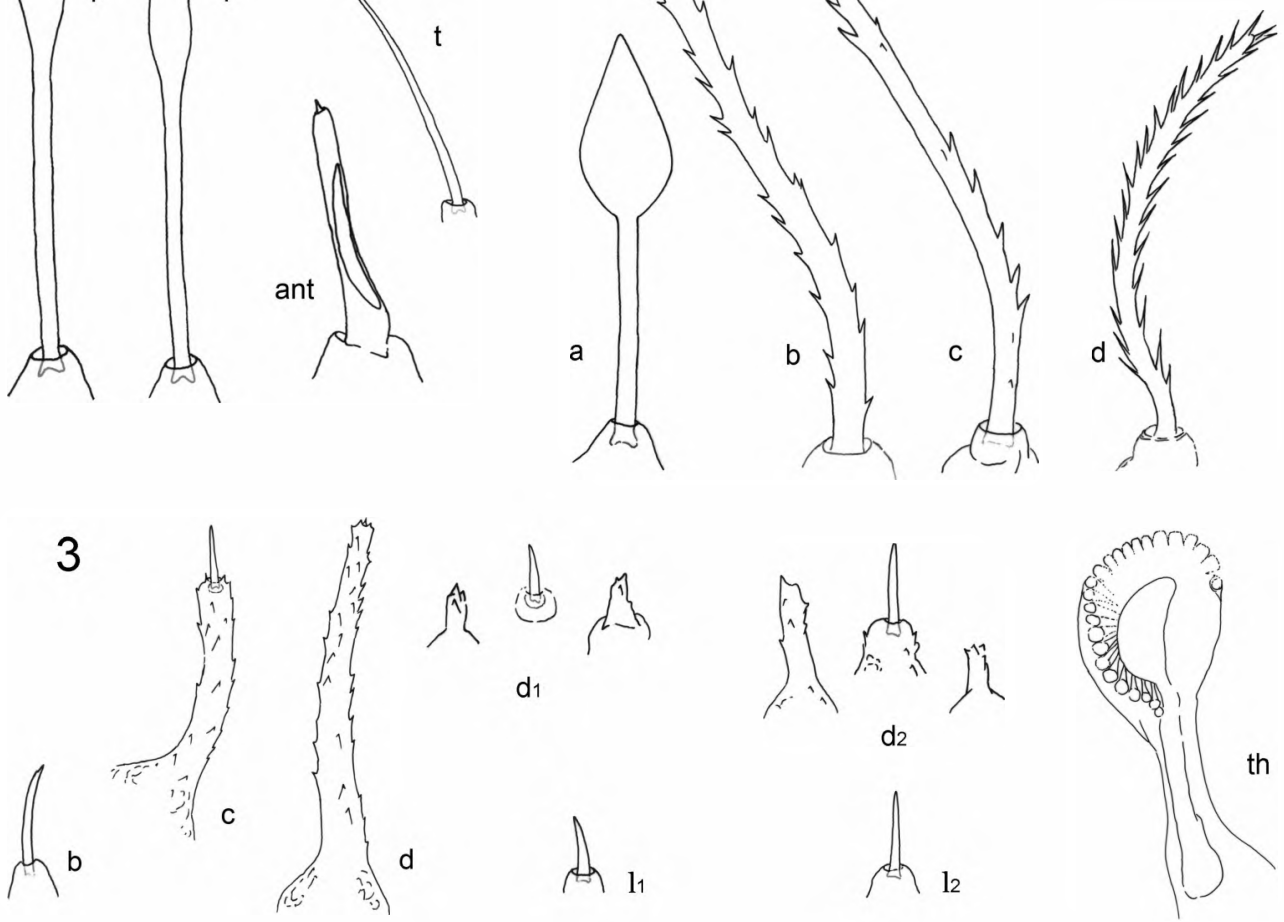

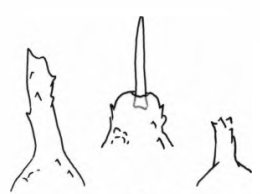

$\mathrm{d}_{2}$

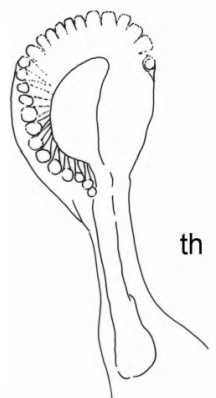

Figs 1-3. Forcipomyia sahariensis Kieffer, 1923, larva (1, 2) and pupa (3). 1 - head setae of larva, 2 - thoracic setae of larva, 3 - processes and thoracic horn of pupa. Abbreviations: $\mathrm{d}$-dorsal, 1 - lateral, ${ }_{1}$ or 2 - the first or the second abdominal segment, th - thoracic horn, ant - antenna, p, q, t - head setae of larva, a, b, c , d - setae and processes of larva or pupa. 
Female: All tibiae with lanceolate scales (Fig. 4); third palpal segment enlarged on basal portion (Fig. $5 \mathrm{f}$ ); antennal ratio AR 0.6-0.8; wing length $1.3-1.4 \mathrm{~mm}$; two seminal capsules present (Fig. 6).

Male: Ventral surface of gonocoxite with a group of $8-10$ distinct spines (Fig. 8). Parameres basally fused, u-shaped, with slender x-crossing apices (Fig. 10). Gonostyle usually pale (Fig. 7). Aedeagus triangular with simple pointed apex (Fig. 9). Wing length 1.3-1.5 mm.
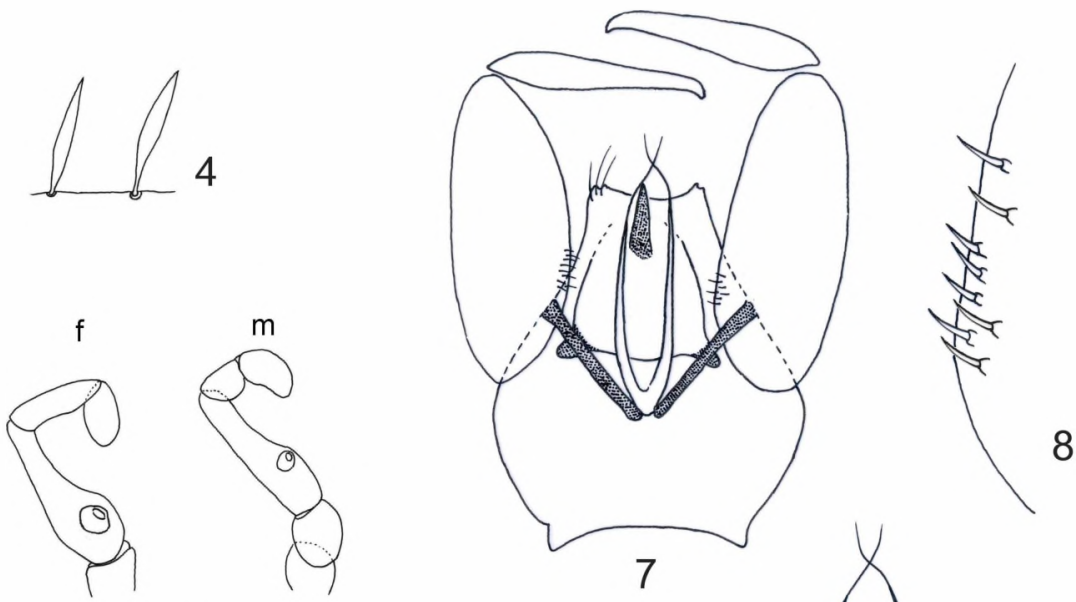

5

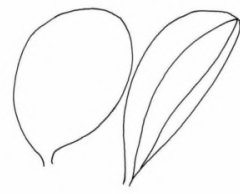

6

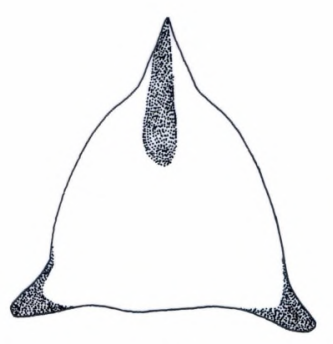

9

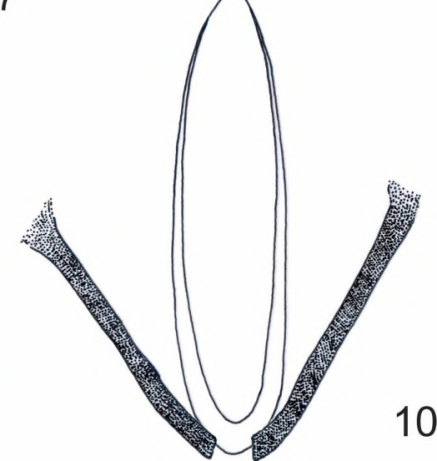

Figs. 4-10. Forcipomyia sahariensis Kieffer, 1923, female (4, 5f, 6) and male (5m, 7-10). 4 - lanceolate scales of hind tibia, 5 - palpus, 6 - seminal capsules, 7 - male genitalia, 8 - ventral surface of gonocoxite with setulae, 9 - aedeagus, 10 - parameres.

Description: Larva (4th instar). Total length 3.7-3.9 mm. Pale yellow.

Head. Antenna slightly curved, pointed. Setae $p$ and $q$ lanceolate, smooth. Seta $t$ smooth and slender with pointed tip (Fig. 1).

Thorax. Prolegs slightly bilobed, hooklets placed centrally. Seta a lanceolate, relatively short, of same shape on all body segments. Seta $b$ and $d$ dark, placed on distinct tubercles, seta $d$ slightly curved, serrated, seta $b$ shorter with dense serratings. Seta $b$ on segment 11 devoid of spines, short and slender. Seta $c$ dark with short sparse spines and pointed apex (Fig. 2). Cuticle covered with short spines.

Seta $d$ of anal segment (12) short and slender, setae $a$ and $b$ of similar shape as on other body segments (Fig. 2). Anal papillae bilobed.

Pupa. Total length $2.8-2.9 \mathrm{~mm}$. Pale yellowish to yellow. 
Head. Process $a$ absent; $b$ bearing very short apical seta (Fig. 3 ).

Thorax. Processes $c, d$ and $e$ stout and serrated. Process $c$ with short seta. Process $f$ reduced to a small tubercle. Horn short, about twice longer than broad, bulb-shaped, with 12-20 spiracular openings (Fig. 3). Caudomedian prolongation reaching middle of 1st abdominal segment.
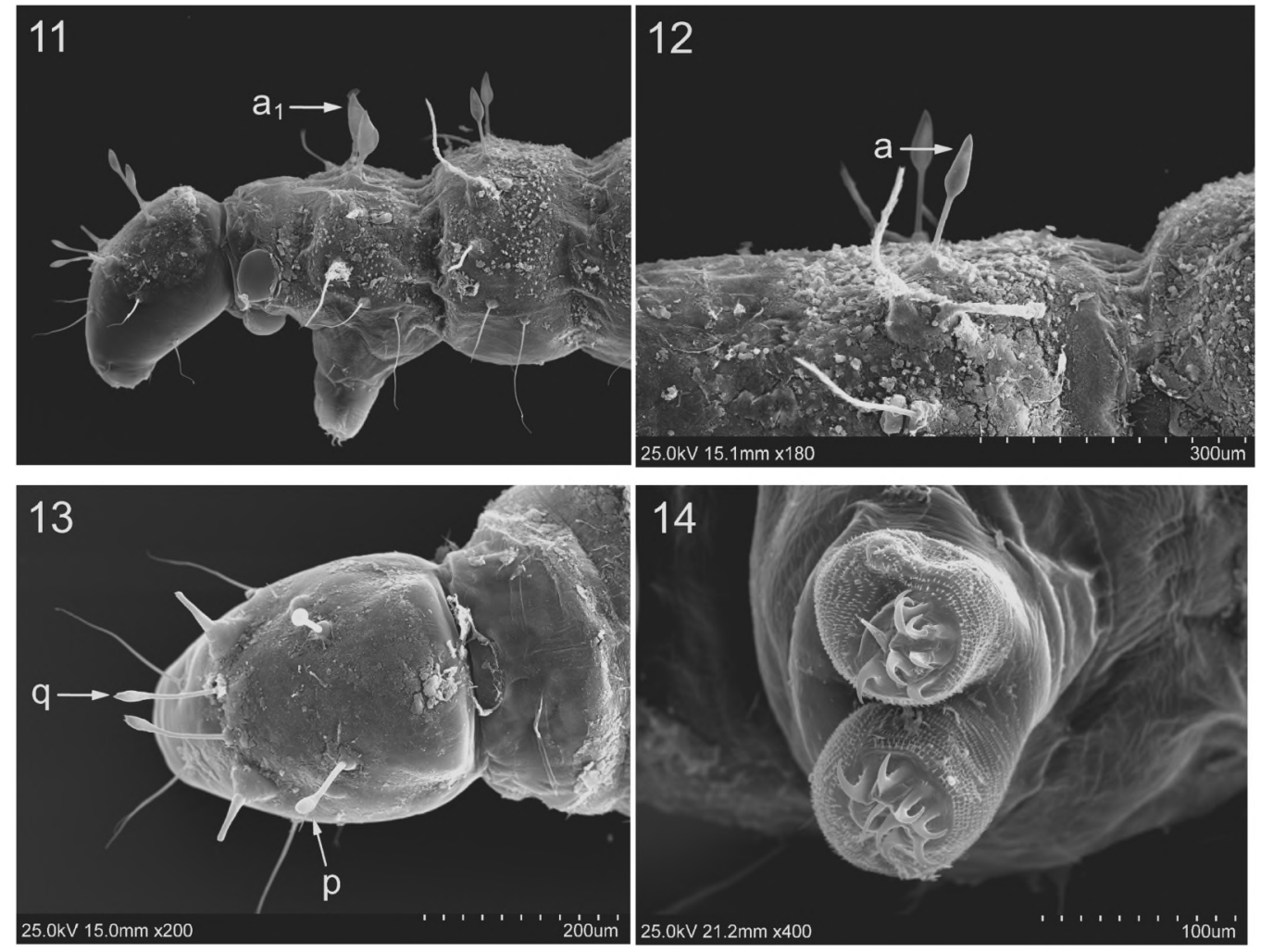

Figs 11-14. Forcipomyia radicicola Edwards, SEM photos of larva. 11 - lateral aspect of head and prothorax, 12 - lanceolate setae of mesothorax, 13 -dorsal aspect of head, 14 -prolegs.

Abdomen. Proximal abdominal segments (1-4) each with 4 pairs of processes: 3 dorsal (d), and 1 lateral $(I)$. Dorsal processes very short, stout and finely serrated. One pair of dorsal and lateral processes with apical short seta (Fig. 3). Segment 5 th only with 2 pairs of processes, 1 dorsal and 1 lateral.

Distribution: Forcipomyia sahariensis is widely distributed in the Palaearctic region. It is recorded from Europe (France, Germany, Poland, Slovakia), Middle Asia (Kazakhstan), Far East (Sakhalin), Near East (Caucasus) and North Africa (Algeria). Larvae and pupae live in wet rotting roots of Arctium lappa and Apiaceae.

\section{DISCUSSION}

Preimaginal stages of Forcipomyia sahariensis are described here for the first time. They are very similar to those of $F$. squamigera. Larvae of both species have similar head setae $p$ and $q$ and thoracic setae $-a, b$ and $d$ (Szadziewski et. al. 2007). The thoracic setae $a$ are short and lanceolate, while $b$ and $d$ serrated and placed on separate tubercles. Pupae of $F$. sahariensis 
and $F$. squamigera have different number and specific shape of short abdominal processess (see key below).

In the male genitalia of Forcipomyia sahariensis there are characteristic u-shaped parameres and a group of 8-10 small spines on the ventral surface of the gonocoxite. The same diagnostic structures we found in males of $F$ tuzeti and $F$ acanthophora described from Europe. We believe that these features properly indicate that all these names concern one species and propose to treat $F$ tuzeti and $F$. acanthophora as new junior synonyms of $F$. sahariensis. Forcipomyia ashantii Ingram \& Macfie, 1924 from tropical Africa and $F$. ventralis Borkent, 1997 (=abdominalis Tokunaga, 1940) from Japan have also ventral spines on gonocoxites like $F$ sahariensis. However, their females have no lanceolate scales on their tibiae.

In the neck region of Forcipomyia radicicola larvae there are three ovoid pillow-like ventral fields of thin and smooth cuticle (Fig. 11). We suggest that they play certainly role in cuticular respiration of apneustic larvae of this species. Such structures in the genus Forcipomyia are observed for the first time.

\section{KEY TO LARVAE ( $4^{\text {TH }}$ INSTAR) OF POLISH SPECIES OF THE SUBGENUS FORCIPOMYIA}

1. Body setae $a$ on segments $2-12$ lanceolate (Figs. 2, 12) ............................................

- Body setae $a$ on segments 2-12 not lanceolate ........................................................9

2. Setae $a$ on prothorax and segments $2-12$ lanceolate, of similar length .............................

- Setae $a$ on prothorax boot-like, short (Fig. 11) ............................... F radicicola Edwards

3. Head setae $p$ and $q$ hair-shaped, serrated .....................................F. costata (Zetterstedt)

- Head setae $p$ and $q$ lanceolate, smooth (Fig.1)

4. Setae $b$ and $d$ on common tubercle; cuticle smooth; apices of prolegs irregular $F$ nigrans Remm, F. hygrophila Kieffer

- Setae $b$ and $d$ on separated tubercles; cuticle with distinct spines, apices of prolegs round .....5

5. Prolegs deeply bilobed on $2 / 3$ total length

- Prolegs shallowly bilobed on $1 / 4$ total length F bipunctata (L.)

6. Seta $b$ straight, with fine and sparse serrations. Body length up $5 \mathrm{~mm}$...F. ciliata (Winnertz)

- Seta $b$ curved, broom-like, with long dense serrations. Body length up to $2,5 \mathrm{~mm}$ ...7

7. Seta $d$ smooth F. pulchrithorax Edwards

- Seta $d$ with dense serrations (Fig. 2)

8. Head seta $t$ bare (Fig. 1) $F$ sahariensis Kieffer

- Head seta $t$ with short spines $F$ squamigera Kieffer

9. Anal papillae bilobed $F$ kaltenbachi (Winnertz)

- Anal papillae single 10

10. Body seta a very long, gradually cylindrical F nigra (Winnertz)

- Body seta a short, swollen at middle with distinct serrations F. brevipennis (Macquart)

\section{KEY TO PUPAE OF POLISH SPECIES OF THE SUBGENUS FORCIPOMYAA}

1. Head with processes (Fig. 3)

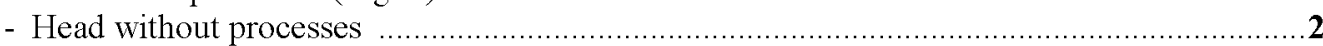

2. Thoracic horn with more than 30 openings. Posterior prolongation of thorax short, reaching middle of 1 st abdominal segment F. ciliata (Winnertz) - Thoracic horn with less than 30 openings. Posterior prolongation of thorax long, reaching almost end of 1 st segment or 2 nd abdominal segment

3. Thorax with long and slender processes $F$ bipunctata (L.)

- Thorax with short processes and tubercles F. pulchrithorax Edwards 
4. Abdominal segments $2-4$ with 1 pair of dorsal processes ...........................................5

- Abdominal segments 2-4 with 2 pairs of dorsal processes (Fig. 3) ..................................6

5. Dorsal process of 1 st abdominal segment short, without seta; dorsal processes of abdominal segments 2-5 without setae; thoracic process $c$ with apical short seta .... F kaltenbachi (Winnertz) - Dorsal process of 1st abdominal segment long, with long apical seta; dorsal process of abdominal segments $2-5$ with long setae; thoracic process $c$ with very long apical seta F. nigrans REMM, F. hygrophila Kieffer

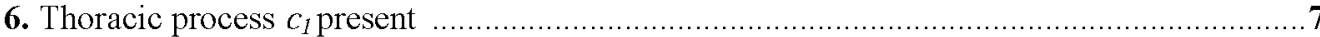

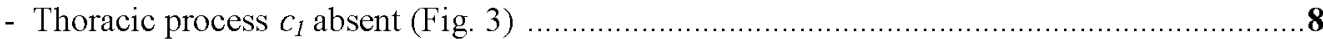

7. Posterior prolongation of thorax short; thoracic process $f$ present $F$ brevipennis (Macquart) - Posterior prolongation of thorax long; thoracic dorsal process $f$ absent, replaced by tubercle F. squamigera (Kieffer)

8. Head with 2 pairs of processes ...................................................... F. nigra (Winnertz)

- Head with 1 pair of processes (Fig. 3) ......................................................................9

9. Head processes with long terminal seta .........................................F. radicicola Edwards

- Head processes without or with short terminal seta ....................................................10

10. Lateral process of abdominal segments long; dorsal thoracic process $f$ present; head process without apical seta ............................................................... F. costata (Zetterstedt) - Lateral process of abdominal segments very short; thoracic dorsal process $f$ absent; head process with apical seta (Fig. 3) ....................................................F sahariensis Kieffer

\section{REFERENCES}

BorkENT A. 2009. World catalog of extant and fossil species of biting midges (Diptera: Ceratopogonidae). http:www.inhs.uiuc.edu/cee/FLYTREE/CeratopogonidaeCatalog.pdf (version 9 July 2009).

BORKENT A. \& WIRTH W. W. 1997. World species of biting midges (Diptera: Ceratopogonidae). Bulletin of the American Museum of Natural History 233: 1-257.

DOMINIAK P. \& MICHALCZUK W. 2009. Two species of biting midges (Diptera: Ceratopogonidae) new to the Polish fauna. Dipteron 25: 8-13. [In Polish, English abstract]

GEKA W. 1996. Immature stages of Forcipomyia kaltenbachi (WINNERTZ) and Forcipomyia nigrans REMM (Diptera: Ceratopogonidae). Polskie Pismo Entomologiczne 65: 9-19.

HAVELKA P. 1976. Limnologische und systematische Studien an Ceratopogoniden (Diptera: Nematocera). Beiträge zur Entomologie 1: 211-306

INGRAM A.\& MACFE J. W. S. 1924. Notes on some African Ceratopogonidae. Species of the genus Forcipomyia. Annals of Tropical Medecine and Parasitology 18: 533-593

KEFFER J. J. 1923. Ceratopogonines recueillis au Sahara Constantinois. Archives de l'Institut Pasteur d'Algèrie 1: 654-683.

REMM H. 1980. New species of the family Ceratopogonidae (Diptera) from the Middle Asia. Tartu Riikliku Ülikodi Toimetised 516: 85-128.

SAUNDERS L. G. 1924. On the life history and the anatomy of the early stages of Forcipomyia (Diptera, Nemat., Ceratopogonidae). Parasitology 16: 164-213.

SZADZIEWSKI R. 1983. Ceratopogonidae (Diptera) from Algeria. II. New species, new records and new synonymy in the genus Forcipomyia Meig. Polskie Pismo Entomologiczne 53: 363-384.

SZADZIEWSKI R. \& BORKENT A. 2003. New synonyms, combinations and records of biting midges (Diptera: Ceratopogonidae). Polskie Pismo Entomologiczne 72: 249-260.

SZADZIEWSKI R. 2007. Ceratopogonidae. In: BOGDANowiCZ W., CHUdZICKA E, PILIPIUK I. \& SKIBRísKA E. (eds) Fauna of Poland - characteristics and checklist of species, Vol.2., pp. 28-29, 62-65. Muzeum i Instytut Zoologii $\mathrm{PAN}, \mathrm{XX}+506 \mathrm{pp}$

SZADZIEWSKI R., GILKA W. \& DOMINIAK P. 2007. A redescription of Forcipomyia squamigera KIEFFER, 1916 in all stages (Diptera: Ceratopogonidae): 275-280. [In:] ANDERSEN T. (ed.) Contributions to the systematics and ecology of aquatic Diptera: A tribute to Ole A. Sæther. The Cadiss Press. Columbus, Ohio. vi $+358 \mathrm{p}$.

ToKUNAGA M. 1940. Biting midges from Japan and neighbouring countries, including Micronesian Islands, Manchuria, north China and Mongolia (Diptera, Ceratopogonidae). Tenthredo 3: 58-100.

WIRTH W. W. \& MARSTON N. 1968. A method for mounting small insects on microscope slides in Canada balsam. Annals of the Entomological Society of America 61: 783-784. 
[Forcipomyia sahariensis KIEFFER (Diptera: Ceratopogonidae) - diagnoza i opis nieznanych weześniej stadiów preimaginalnych]

W niniejszej pracy przedstawiono diagnozy wszystkich stadiów rozwojowych Forcipomyia sahariensis Kieffer. Szczególowo opisano nieznane dotąd larwy i poczwarki tej szczeciorki. Forcipomyia tuzeti Huttel et Huttel, 1952 oraz F acanthophora Remm, 1976 zostaly uznane za młodsze synonimy $F$. sahariensis Kieffer. Uzupelniono także klucze do oznaczania larw i poczwarek podrodzaju Forcipomyia w Polsce, dodając obecnie omawiany gatunek szczeciorki wraz z dwoma innymi: F. squamigera Kieffer i F. radicicola Edwards. 